\title{
EDUKASI PULAU WISATA AMAN COVID-19 DI DESA LEMUKUTAN KECAMATAN SUNGAI RAYA KEPULAUAN KABUPATEN BENGKAYANG PROVINSI KALIMANTAN BARAT
}

\author{
Fauzan Alfikrie ${ }^{1 *}$, Uti Rusdian Hidayat ${ }^{2}$, Mimi Amaludin ${ }^{3}$, Madaniah $^{4}$ \\ 1-4 STIKes Yarsi Pontianak
}

Email Korespondensi: ners.fauzan06@gmail.com

Disubmit: 07 September 2021 Diterima: 23 Desember $2021 \quad$ Diterbitkan: 02 Januari 2022 DOI: https://doi.org/10.33024/jkpm.v1i1.5081

\begin{abstract}
ABSTRAK
Covid-19 sangat mudah menular diantara masyarakat, terutama ditempattempat keramaian terutama daerah wisata. Banyak masyarakat yang tidak mematuhi anjuran kesehatan terhadap protokol kesehatan disebabkan pengetahuan yang rendah tentang covid-19. Tujuan pengabdian kepada masyarakat untuk meningkatkan pengetahuan dan keterampilan masyarakat tentang pencegahan covid-19 di Desa Lemukutan. Metode palaksanaan pengabdian kepada masyarakat adalah penyuluhan tentang covid-19 dan skrining covid-19 kepada masyarakat Desa Lemukutan. Hasil pengabdian kepada masyarakat didapatkan data sebelum edukasi diperoleh tingkat pengetahuan dan kemampuan masayarakat dalam melakukan skrining covid-19 pada kategori kurang $43,3 \%$, kategori cukup 33,3\%, dan kategori baik 23,4\%. Sedangkan setalah diberikan edukasi terjadi peningkatan pengetahuan dan kemampuan masayarakat dalam melakukan skrining covid-19 pada kategori cukup 30\% dan kategori baik 70\%. Peningkatan pengatahuan masyarakat tentang covid-19 dan kemampuan dalam melakukan skrining covid-19 menjadi salah satu upaya pencegahan covid-19.
\end{abstract}

Kata Kunci: Edukasi, Skrining, Covid-19

\begin{abstract}
Covid-19 is very easy to spread among people, especially in crowded places, especially tourist areas. Many people do not comply with health recommendations regarding health protocols due to low knowledge about COVID-19. The purpose of community service is to increase community knowledge and skills about preventing COVID-19 in Lemukutan Village. The method of implementing community service is counseling about covid-19 and COVID-19 screening training to the people of Lemukutan Village. The results of community service obtained data before education obtained the level of knowledge and ability of the community in screening for COVID-19 in the less category $43.3 \%$, the sufficient category $33.3 \%$, and the good category $23.4 \%$. Meanwhile, after being given education, there was an increase in the knowledge and ability of the community in screening for COVID-19 in the 30\% sufficient category and $70 \%$ good category. Increasing public knowledge about COVID-19 and the ability to screen for COVID-19 is one of the efforts to prevent COVID19.
\end{abstract}

Keywords: Education, Screening, Covid-19. 


\section{PENDAHULUAN}

Coronavirus disease 19 (Covid-19) pertama kali ditemukan di wuhan, China. Penyakit ini disebabkan oleh severe acute respiratory syndrome coronavirus 2 (SARS-CoV-2) yang merupakan gangguan pernapasan akut yang parah (KemenkesRI, 2020). Penyebaran Covid-19 sangat cepat dan telah menyebar ke 218 Negara di dunia. Data WHO pada tanggal 3 Juni 2021 jumlah kasus covid-19 telah mencapai 172.405.986 kasus (WHO, 2021). Di Indonesia, data jumlah kasus covid-19 mencapai 1.837.126 kasus dengan jumlah kematian 51.095 kasus (KemenkesRI, 2021). Penyebaran covid-19 di Indonesia telah mencapai 34 provinsi, termasuk Kaslimantan Barat dengan angka kejadian terkonfirmasi positif covid-19 pada tanggal 3 Juni 2021 mencapai 11.153 kasus. Kota Pontianak menempati urutan pertama dengan jumlah kasus konfirmasi terbanyak yaitu 2022 kasus, Landak 1187 kasus, Sintang 1181 kasus dan Kubu Raya 989 Kasus. Sedangkan Kabupaten Bangkayang berada pada urutan ke-9 dengan jumlah kasus covid-19 yaitu 575 kasus (Dinkes-Kalbar, 2021).

Covid-19 menyebar dengan sangat cepat, virus ini menular antara hewan dan manusia (zoonosis) (KemenkesRI, 2020). Penularan dapat terjadi antar manusia yang bergejala ke orang lain melalui media seperti percikan dahak seperti batuk, bersin dan berbicara (WHO, 2020). Penyebaran semakin cepat pada tempat-tempat keramaian seperti pasar, tempat umum, dan tempattempat wisata. Pulau lemukutan merupakan salah satu tempat wisata yang terdapat di Kabupaten Bangkayang Provinsi Kalimantan Barat. Wisata Pulau Lemukutan sangat menjanjikan dengan menyediakan pemandangan yang indah, wisata terumbu karang, spot foto yang unik sehingga banyak wisatawan yang tertarik untuk berkunjung. Masih tingginya resiko penularan virus corona dari satu orang ke orang lainnya, mengharuskan penerapan protokol kesehatan di tempat wisata wajib dipatuhi. Pemerintah telah mengatur penerapan protokol kesehatan di tempat wisata melalui PERGUB Prov. Kalimantan Barat No. 110 Tahun 2020 tentang penerapan disiplin dan penegakan hukum protokol kesehatan sebagai upaya pencegahan dan pengendalian corona virus disease 2019. Namun, pada kenyataannya penerapan protokol kesehatan covid-19 masih belum sepenuhnya dilaksanakan.

Beberapa factor yang berkontribusi terhadap ketidakpatuhuan masyarakat dalam menerapkan protokol kesehatan covid-19 yaitu jenis kelamin, tingkat Pendidikan, sikap dan pengetahuan masyarakat (Wiranti, Sriatmi, \& Kusumastuti, 2020). Selain itu, penyebab kepatuhan masyarakat yang kurang dalam menerapkan protokol kesehatan disebabkan oleh pengetahuan yang rendah, norma sosial, konsekuensi keuangan karena kehilangan pekerjaan dan sikap dalam penerapan dalam penerapan protokol kesehatan covid-19 (Alfikrie, Akbar, \& Anggreini, 2021; Webster et al., 2020).

Hasil studi pendahuluan kepada lima orang masyarakat di desa pulau lemukutan tentang protokol kesehatan covid-19 diperoleh data bahwa 5 orang memiliki pengetahuan yang cukup, 4 orang memiliki pengetahuan kurang dan satu orang memiliki pengetahuan baik. Hasil wawancara juga dilakukan kepada pemerintah desa bahwa belum ada proses skrining atau pemeriksaan kesehatan kepada wisatawan yang berkunjung seperti pemeriksaan suhu tubuh, pemeriksaan riwayat bepergian dan pemeriksaan riwaya kontak erat dengan pasien covid-19. Selain itu, hasil observasi penerapan protokol kesehatan juga tidak dilakukan oleh beberapa pengunjung seperti tidak menjaga jarak dan tidak menggunakan masker Sehingga, hal ini dapat meningkatkan resiko penularan covid-19 pada tempat wisata. 
Upaya yang dapat dilakukan untuk mengatasi masalah yang dialami dengan memberikan edukasi dan pelatihan kepada masyarakat tentang pengetahuan covid-19 dan proses skrining pengunjung pada masa pandemic. Hal ini bertujuan untuk mengendalikan dan menekan resiko penularan covid19 di tempat-tempat wisata. Pemberian edukasi yang tepat dan mudah dimengerti dengan media yang baik yang ditujukan kepada masyarakat dapat meningkatkan pengetahuan tentang penerapan protokol kesehatan pencegahan covid-19 (Rumagit, 2020). Terutama dalam penerapan 3M yaitu menjaga jarak, memakai masker dan mencuci tangan dalam usaha pencegahan covid-19 (Wulandini, Fitri, \& Ilham, 2021).

Berdasarkan permasalahan yang ditemui diperlukan edukasi dan pelatihan bagi masyarakat untuk meningkatkan pengetahuan serta kemampuan dalam melakukan evaluasi terhadap masyarakat dengan resiko covid-19. Tujuan pengabdian masyarakat adalah untuk meningkatkan pengetahuan dan kemampuan dalam proses skrining tentang pencegahan covid-19.

\section{MASALAH}

Penerapan protokol kesehatan yang dilakukan ditempat wisata desa Lemukutan selama masa pandemic masih belum optimal, tidak ada skrining kesehatan, masih banyak masyarakat yang tidak menggunakan masker saat masuk kedalam pulau lemukutan dan tidak menjaga jarak. Kondisi seperti ini tentu dapat meningkatkan resiko peningkatan penularan covid pada masyarakat. Untuk meminimalkan resiko penularan perlu adanya edukasi kepada masyarakat dan proses skrining oleh petugas di tempat wisata. Peningkatan pemahaman masyarakat dapat dilakukan melalui edukasi kepada masyarakat dalam pencegahan covid 19 dan upaya skrining masyarakat yang berkunjung dapat dilakukan dengan melakukan pelatihan kepada masyarakat dalam melakukan skrining covid-19.

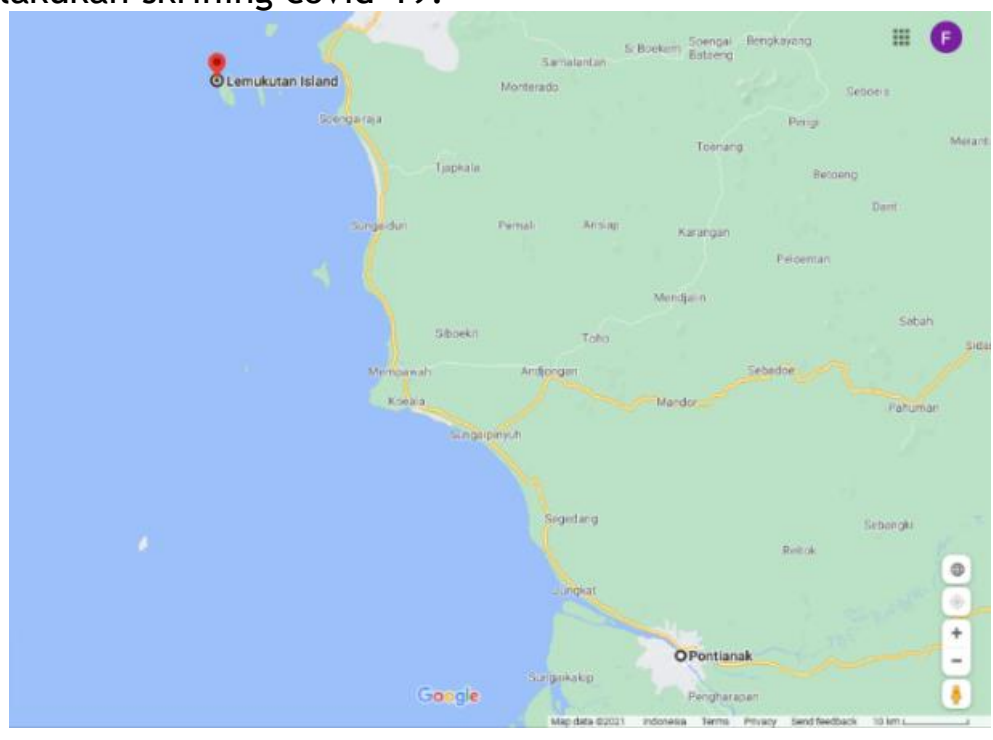

Gambar 1. Peta lokasi dan jarak Pontianak ke mitra kerjasama (pulau lemukutan) 


\section{METODE}

a. Tahap Persiapan

Tahap persiapan dilakukan dengan mengidentifikasi masalah yang ada pada masyarakat, melakukan studi pendahuluan dengan wawancara kepada masyarakat dan menentukan solusi terhadap masalah yang dialami. Pada tahap persiapan, tim pelaksanan pengabdian kepada masyarakat mengurus perizinan dengan pemerintah desa dan membuat perencanaan pelaksanaan pengabdian kepada masyarakat. Selain itu, tim pelaksana pengabdian kepada masyarakat juga berkoordinasi dengan mitra pengabdian untuk penyediaan tempat pelaksanaan pengabdian dan penyebaran undangan kepada masyarakat.

b. Tahap Pelaksanaan

Pelaksanaan pengabdian kepada masyarakat dilakukan dengan beberapa tahapan yaitu:

1) Pembukaan oleh moderator

2) Pengukuran pengetahuan dan kemampun dalam skrining sebelum edukasi dan pelatihan

3) Pemberian materi edukasi tentang covid-19 dan pelatihan skrining covid-19 pada tanggal 1 September 2021 pada pukul 08.30 sampai dengan 09.30 WIB. Metode yang digunakan berupa ceramah dan demonstrasi skrining covid-19 yang interaktif.

4) Pengukuran pengetahuan dan kemampun dalam skrining sesudah edukasi dan pelatihan

5) Penutupan kegiatan

c. Evaluasi

Evaluasi dibagi menjadi tiga bagian yaitu:

1) Evaluasi struktur

Jumlah peserta yang hadir adalah 30 orang, sesuai dengan perencanaan yang telah disusun. Pengaturan tempat diberikan jarak dan masyarakat menggunakan masker saat diruangan. Ventilasi di ruangan sangat memadai sehingga sirkulasi udara sangat baik. Proses penyampaian materi menggunakan media dan perelatan sesuai dengan perencanaan.

2) Evaluasi proses

Pelaksanaan edukasi dan pelatihan skrining covid-19 dilakukan di balai desa Pulau Lemukutan pada pukul 08.30 sampai dengan 09.30 WIB. Proses pelaksaan berjalan dengan lancar, semua peserta aktif saat berdiskusi dan mencoba cara melakukan skrining covid-19 yang dibantu oleh fasilitator.

\section{HASIL DAN PEMBAHASAN}

Pelaksanaan pengabdian kepada masyarakat dilakukan pada masyarakat Desa Pulau Lemukutan dengan jumlah 30 peserta. Hasil pengabdian kepada masyarakat dijelaskan pada tabel 1.

Tabel 1. Distrbusi Frekuensi Pengetahuan Peserta Sebelum dan Setalah Edukasi dan Pelatihan Skrining Covid-19 $(n=30)$

\begin{tabular}{cllll}
\hline \multirow{2}{*}{ Kategori } & \multicolumn{2}{c}{ Sebelum } & \multicolumn{2}{c}{ Setalah } \\
\cline { 2 - 5 } & $\mathrm{f}$ & $\%$ & $\mathrm{f}$ & $\%$ \\
\hline Rendah & 13 & 43,3 & 0 & 0 \\
\hline Sedang & 10 & 33,3 & 9 & 30 \\
\hline Tinggi & 7 & 23,4 & 21 & 70 \\
\hline
\end{tabular}


Tabel 1 menjelaskan bahwa sebelum diberikan edukasi dan pelatihan skrining covid-19 sebagian besar peserta memiliki pengetahuan dan kemampuan skrining pada kategori rendah yaitu 43,3\%, kategori sedang yaitu $33,3 \%$ dan kategori tinggi yaitu $23,4 \%$. Sedangkan setelah diberikan edukasi dan pelatihan skrining covid-19 diperoleh pengetahuan dan kemampuan dalam skrining covid-19 pada kategori baik yaitu 70\% dan kategori sedang yaitu $30 \%$. Hasil pengabdian kepada masyarakat menjelaskan bahwa edukasi dan pelatihan skrining covid-19 meningkatkan pengetahuan dan kemampuan masyarakat dalam pencegahan dan skrining covid-19.

Edukasi dan pelatihan merupakan salah satu upaya dalam meningkatkan pengetahuan kelompok masyarakat. Kegiatan edukasi dan sosialisasi tentang pencegahan dari penularan virus COVID-19 menjadi hal yang sangat penting dan dilakukan secara konsisten, sehingga perilaku dan kesadaran masyarakat dalam menjaga kesehatan serta menerapkan PHBS terutama dalam masa pandemic dapat diandalkan (Caesaron, Salma, Prasetio, \& Rifai, 2021). Program edukasi dan sosialisasi bertujuan untuk peningkatan pengetahuan masyarakat dalam penerapan adaptasi kebiasaan baru pada masa pandemic (Anafib, Kameswari, Rahmadani, Azmi, \& Indarwati, 2020).

Program edukasi dan pelatihan merupakan metode yang baik untuk meningkatkan pengetahuan dan keterampilan seseorang untuk tujuan tertentu dalam melakukan tugas dan pekerjaan (Marquis \& Huston, 2012). Pengetahuan merupakan bagian yang sangat penting untuk menentukan sikap dan perilaku seseorang. Pengetahuan memiliki hubungan yang positif dengan perilaku seseorang. Pengetahuan yang baik dapat memicu perubahan perilaku seseorang. Sehingga semakin tinggi pengetahuan maka semakin baik pula tindakan seseorang dan begitu pula sebaliknya (Notoatmodjo, 2012).

Faktor pendukung kegiatan pengabdian kepada masyarakat adalah adanya dukungan dari pemerintah Desa Lemukutan, masyarakat yang aktif dalam kegiatan pengabdian kepada masyarakat, kegiatan edukasi dan pelatihan yang diikuti peserta sampai selesai. Sedangkan faktor pengahambat dalam kegiatan pengabdian kepada masyarakat adalah kesulitan mengumpulkan banyak peserta karena akibat Pandemi Covid-19.

Kegiatan pengabdian kepada masyarakat di Desa Lemukutan telah terdokumentasi dengan baik. Berikut gambar pelaksanaan kegiatan pengabdian kepada masyarakat di Desa Lemukutan (gambar 1).
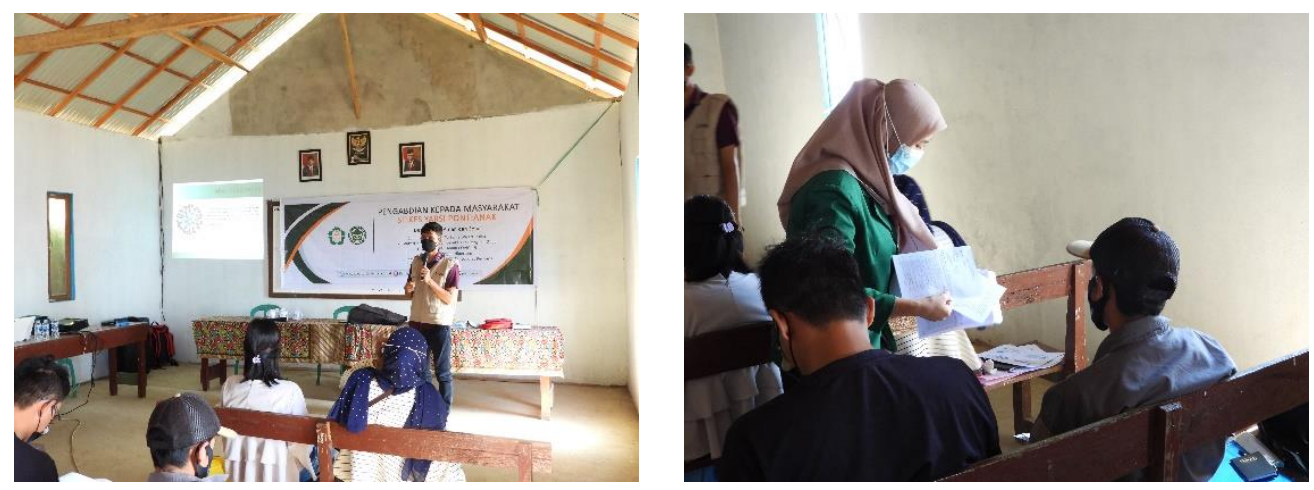

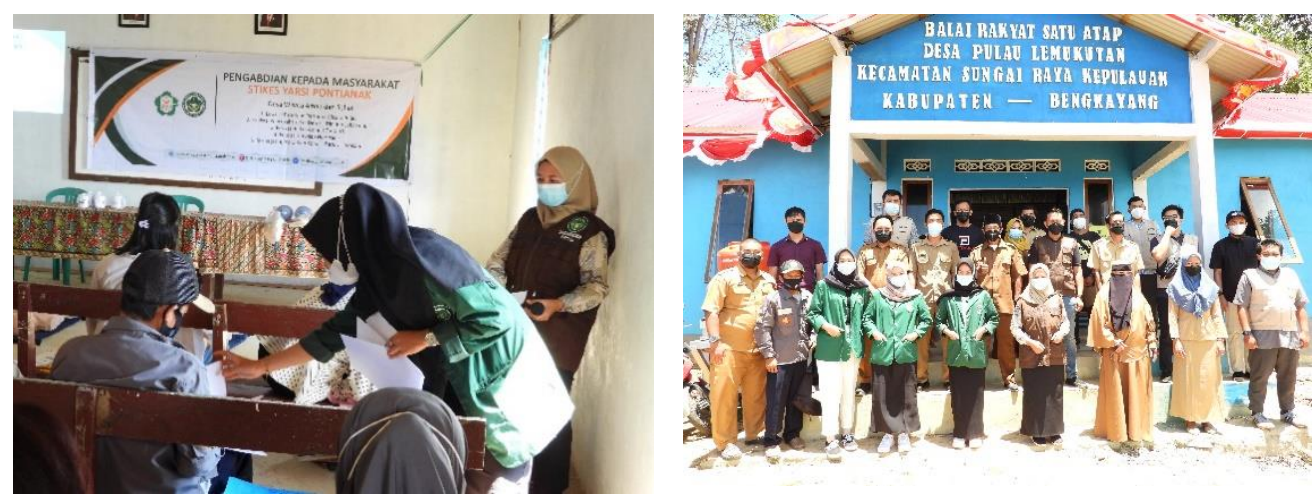

Gambar 1. Kegiatan Pengabdian Kepada Masyarakat di Desa Lemukutan

\section{KESIMPULAN}

Berdasarkan hasil pengabdian kepada masyarakat terdapat peningkatan pengetahuan dan kemampuan masyarakat tentang pencegahan dan penularan covid-19 serta skrining covid-19.

\section{DAFTAR PUSTAKA}

Alfikrie, F., Akbar, A., \& Anggreini, Y. D. (2021). Pengetahuan dan sikap mahasiswa dalam pencegahan covid-19. Borneo Nursing Journal, 3(1), 39-44.

Anafib, H. F., Kameswari, S. P., Rahmadani, F., Azmi, M. U., \& Indarwati, S. A. D. (2020). Edukasi pencegahan covid-19 dengan proses adaptasi baru "New Normal" di Salatiga. Retrieved from https://kkn.unnes.ac.id/lapkknunnes/32004_3373011003_6_Kelurahan \%20_20200925_052442.pdf

Caesaron, D., Salma, S. A., Prasetio, M. D., \& Rifai, M. H. (2021). Edukasi dan sosialisasi pencegahan dan pengendalian COVID-19 melalui media poster di Desa Bojongsoang, Kabupaten Bandung. J Abdimas: Jurnal Pengabdian Masyarakat Universitas Merdeka Malang, 6(2), 221-229.

Dinkes-Kalbar. (2021). Kategori Resiko Kenaikan Kasus Kabupaten/Kota Provinsi Kalimantan Barat. Retrieved from https://dinkes.kalbarprov.go.id/covid19/

KemenkesRI. (2020). Pedoman Pencegahan Dan Pengendalian Coronavirus Disesase. Retrieved from https://covid19.go.id/p/protokol/pedomanpencegahan-dan-pengendalian-coronavirus-disease-covid-19-revisi-ke-5

KemenkesRI. (2021). Covid-19. $\quad$ Retrieved from https://infeksiemerging.kemkes.go.id/dashboard/covid-19

Marquis, B. L., \& Huston, C. J. (2012). Leadership Roles and Management Functions in Nursing: Theory and Application (A. Jordan Ed. 7th edition ed.). Philadelpia: Lippincott Williams \& Wilkins.

Notoatmodjo, S. (2012). Promosi Kesehatan dan Perilaku Kesehatan. Jakarta: PT.RINEKA CIPTA.

Rumagit, S. (2020). Pengaruh pendidikan kesehatan terhadap pengetahuan pencegahan covid-19 pada masyarakat Kaweng. E-Jurnal UNSRIT, 7(3).

Webster, R. K., Brooks, S. K., Smith, L. E., Woodland, L., Wessely, S., \& Rubin, G. J. (2020). How to improve adherence with quarantine: rapid review of the evidence. J Public Health, 182, 163-169. 
WHO. (2020). Clinical management of severe acute respiratory infection (SARI) when COVID-19 disease is suspected. Retrieved from https://www.who.int/docs/default-source/coronaviruse/clinicalmanagement-of-novel-cov.pdf

WHO. (2021). WHO Coronavirus (COVID-19) Dashboard: Situation by Region, Country, Territory \& Area. Retrieved from https: //covid19. who.int/table

Wiranti, W., Sriatmi, A., \& Kusumastuti, W. (2020). Determinan kepatuhan masyarakat Kota Depok terhadap kebijakan pembatasan sosial berskala besar dalam pencegahan COVID-19. Jurnal Kebijakan Kesehatan Indonesia: JKKI, 9(3), 117-124.

Wulandini, P., Fitri, A., \& Ilham, M. R. R. (2021). Pengaruh Pendidikan Kesehatan Terhadap Perilaku 3m Pencegahan Covid-19 Pada Ibu Pkk Di Desa Rambah Hilir Timur Tahun 2021. J Al-Tamimi Kesmas: Jurnal Ilmu Kesehatan Masyarakat, 10(1), 6-15.

Zainaro, M. A., Andoko, A., \& Rahmawati, R. P. (2021). Hubungan Pengetahuan dan Sikap Terhadap Kejadian Covid-19 pada Masyarakat di Kelurahan Mulyojati Kota Metro. Malahayati Nursing Journal, 3(4), 517528. 